(C) Springer-Verlag 2006

$10.1007 / \mathrm{s} 00114-006-0130-1$

\title{
Driving forces from soil invertebrates to ecosystem functioning: the allometric perspective
}

\section{Christian Mulder1}

(1) Laboratory for Ecological Risk Assessment, National Institute for Public Health and Environment (RIVM), A. van Leeuwenhoeklaan 9, P.O. Box 1, 3720 BA

Bilthoven, The Netherlands

Email: christian.mulder@rivm.nl

\begin{abstract}
The European soil policy is being focussed towards a more conscious and sustainable use of the soil, taking into account ecological, economical and societal dimensions. Living soil organisms are reliable bioindicators, as they provide the best reflection of the soil system, ecological services and ecosystem functioning therein. These most complex (bio)physical systems indicate, among others, the energy flow. Such processes can be described by rather simple power law relationships. In fact, the average body mass (dry weight) can be seen as an inherent species property, while population density is a much more flexible parameter reflecting ecosystem state. In this study, I review the interactions between these items in relation to feedbacks and conjectured relationships which can be seen as ecological networks. From this novel perspective, allometry can be used as an integrated measure for the anthropogenic influence on landscapes and related food webs. Allometry is, therefore, a perfect surrogate for land use intensity in modelling of field effects for restoration ecology and conservation biology. Robust correlations will be addressed between the density dependence of invertebrates and the ability of soil systems themselves to recover after disturbance. Quantitative indicators of soil community composition and related ecological services are proposed and their application for ecological risk assessment is illustrated.
\end{abstract}

\section{Introduction}

One of the major scientific issues arising from recent ecological investigations is the relation between structural biodiversity and functional processes. Many studies addressed the variability of aboveground ecosystems with different productivity (Watkinson and Freckleton 1997; Hartnett and Wilson 1999;

Klironomos et al. 2000; Bradford et al. 2002; Wardle 2002; Mulder and De Zwart 2003; Bardgett et al. 2005). A wide variation across ecosystems arises from several sources including soil factors (e.g. texture, priming effect of organic matter), litter quality and quantity, and the competition for mineral nutrient availability in the primary decomposer community (Chapin and Eviner 2003; Fontaine et al. 2004). Soil characteristics exert strong controls over ecosystem processes such as nutrient cycling and litter decomposition rate while affecting organisms' abundance and turnover rates. Fungal hyphae are considered to play a crucial role in the stabilisation of soil macroaggregates $(>250 \mu \mathrm{m})$, in synergy with plant root exudates and secretions by microorganisms that seem to promote further formation and stabilisation of soil microaggregates. Wardle et al. (2004) couple a relative fungal dominance in the soils to nutrient-poor litter, whereas for fungal diversity and spore production the opposite often occurs (Mulder and Janssen 1999; Mulder et al. 2005a). As only (some) bacteria are - like plants - 
(photo)autotrophic organisms, most of the microorganisms are heterotrophic. Thus, when free components of the fresh organic matter (FOM) reach the soil, either as surface litter or as detached/consumed root litter, the heterotrophic respiration starts with the decomposing process of converting the organic carbon in the litter to $\mathrm{CO} 2$, making nitrogen available for plants. The decomposition rate is influenced by the chemical nature of carbon (cellulose vs lignin), by the microbial pools (Beerling and Woodward 2001; De Boer et al. 2005) and by the soil animals themselves (Cole et al. 2004; Moore et al. 2004). The predictions of effects of land use change on soil animals are usually based on habitat-response models derived from the present-day faunal distribution. Especially resources availability changes are key to the response of organisms. In this review, I will illustrate this straightforward cause-effect relationship from an allometric perspective that enables the detection of reference assemblages of organisms which can be regarded as sustainable and stable. Only within such assemblages does a host of organisms ranging from earthworms and nematodes to bacteria and fungi interact in ways beneficial to each other.

\section{Resources and mobility}

The aboveground vegetation obviously governs the quality and quantity of plant litter produced within an ecosystem which in turn influences the soil quality. Organic inputs such as root exudates and plant remains may compensate further carbon losses through mineralisation. Water-soluble organic matter (fresh carbohydrate and protein content) is considered a labile soil fraction that is easily degradable by microorganisms and is supposed to express the potential of a given ecosystem to support specific microbial activity (Cook and Allan 1992; De Luca and Keeney 1993). However, organic matter contained within small aggregates is much more protected from microbial attack, becoming more resistant to decomposition (Ashman et al. 2003). The dead organic matter fraction in soil increases with the fraction of silt and clay particles and is therefore strongly related to the soil texture. As soil organic matter (SOM) has an intrinsically low quality, its decomposition is accelerated by the supply of fresh organic matter (FOM), like plant litter and straw. FOM, in fact, contains many energy-rich carbon compounds (Fontaine et al. 2004; Fontaine and Barot 2005) that are absorbed by microbial r-strategists (Fig. 1, bottom). According to Fontaine et al. (2003), an acceleration of the decomposition rate of SOM may occur as soon a substantial part of FOM becomes absorbed by microbial Kstrategists dominating the SOM decomposition process (Fig. 1, top). Comparable controlled interrelationships in the exchanges of biogenic carbon between main carbon fluxes are widespread also in pelagic food webs (e.g. Cohen 1994;

Legendre and Rivkin 2002). 


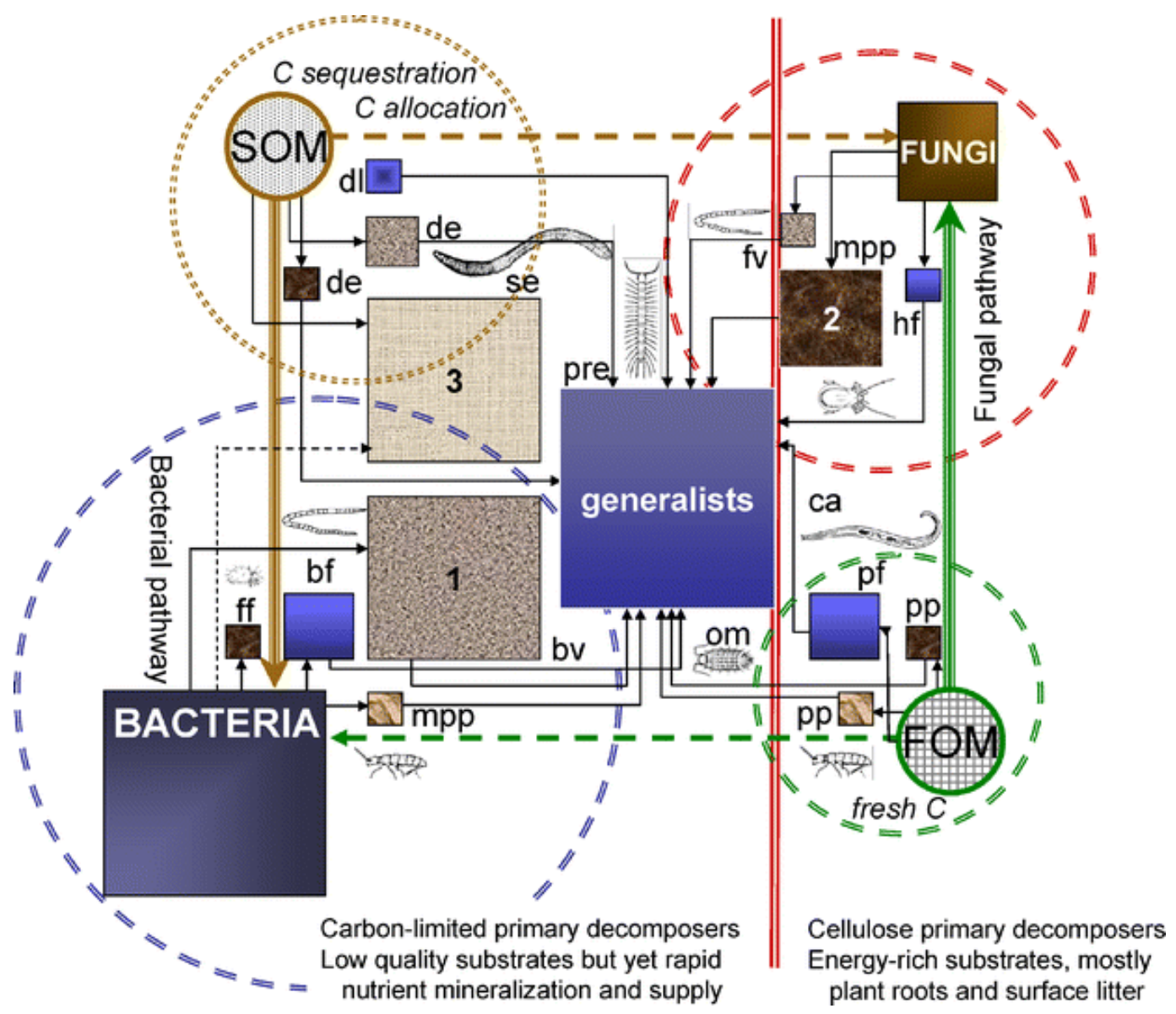

Fig. 1 Main feedbacks and trophic links in a typical agroecosystem [bottom right: fresh organic matter (FOM); top left: soil organic matter (SOM)]. Bacterial pathway on the left, fungal pathway on the right. 1 , enchytraeids; 2 , mites; 3 , earthworms, no numbers indicate either collembolans (paper-textured boxes) or nematodes (blue-greyish boxes). Trophic categories and life strategies: bf (bacterial-feeding nematodes), bv (bacterivore enchytraeids), ca (carnivore nematodes), de (soil detritivore mites and enchytraeids), dl (Dauerlarvae, the only nematode resting stage), ff (filter-feeding histiostomatid mites), fv (fungivore enchytraeids), hf (hyphal-feeding nematodes), mpp [microphytophagous collembolans (mostly high grazing rates) and mycophagous oribatid and prostigmatid mites (low grazing rates)], om [omnivore (micro)arthropods and non-parasitic nematodes], pf (plant-root-feeding nematodes), pp (phytophagous microarthropods, mostly engulfers and fluid feeders), pre (fluid feeders and nematophagous predating mites), se (all endogeic soil engineers, earthworms)

There is a wide laboratory evidence for an extremely effective competition between microbes and plants for the nutrients uptake in soil systems (e.g. Setälä et al. 1998; Laakso et al. 2000). These key cycles support the life of all terrestrial organisms (Setälä 2002; Wardle et al. 2004; De Deyn and Van der Putten 2005). A further stabilising effect of detritus can be achieved not only through selflimitation of the resource but rather as the result of a constant input (Wardle 1995,2002 ) that can be resumed in the statement: The threat of vital soil processes can be expressed by comparing the number of species in functional groups of a certain area with its reference (undisturbed locations). Due to functional redundancy, most soil processes are assumed to continue to exist with 
fewer species, in which case the risk of ecosystem instability and uncontrolled fluctuations will increase (Breure 2004). Recent studies involving soil nematodes (Perez-Moreno and Read 2001), Oligochaeta (Hedlund et al. 2004) and insects (Klironomos and Hart 2001; Filser et al. 2002) have emphasised the likely importance of mycorrhizal fungi in the facilitation of processes such as nitrogen recycling (e.g. Jansa et al. 2002), among others, through dead organic matter (i.e. faunal necromass and plant remains). Microbial communities occurring in the topsoil cannot access groundwater and must rely solely on soil moisture available from precipitation. Regardless the rainfall extent, the vegetation continues to assimilate (from) SOM and to deliver FOM to the soil (Fig. 1), but during the dry season the physical conditions of the soil system may be too excessive to allow for commensurate increases in the microbial carbon degradation rate.

Furthermore, increased land use may result in rapid declines in SOM due to reduced input rates, increased FOM decomposability and decreased physical protection to decomposition (for example, by cropping and tillage effects). Therefore, it remains important to integrate spatial and temporal nonlinearities at disparate scales in the detrital soil food web models to produce more realistic predictions of potential effects of human impact, management regime and global change.

The largest proportion belowground of that organic matter apparently consists in many terrestrial ecosystems of fungal mycelium (Högberg and Högberg 2002). Perez-Moreno and Read (2001) investigated the degradation of necromass aliquots of a bacterial-feeding nematode. Within six and one half months, a paxilloid fungus reduced the $\mathrm{N}$ content of that necromass by $68 \%$ in mycorrhizal systems, whereas the equivalent value for non-mycorrhizal systems was only $37 \%$ (Read and Perez-Moreno 2003). Gains of nitrogen were particularly high, suggesting possible $\mathrm{N}$-fixing activities that may have been enhanced (PerezMoreno and Read 2001; Read and Perez-Moreno 2003). The potential adverse effects of the activities of fungivore organisms in the rhizosphere upon the functioning of specific host-mycorrhiza symbioses have also been addressed (Fitter and Sanders 1992; Klironomos and Kendrick 1995, 1996; Setälä 1995, 2002; Gange and Brown 2002). Mycorrhizal systems (such as the ectomycorrhizal roots investigated by Högberg and Högberg 2002) are extremely important for the production and leaching of dissolved organic carbon. Thus, the actual response of the individuals occurring in a community to the FOM to SOM ratio (as to other possible environmental changes) remains a particularly important topic in ecosystem stability. Species occurrence in any ecosystem strongly depends on a huge variety of coupled habitat criteria in terms of compatible physical and chemical conditions and multiple trophic interactions, such as competition, predation, reproduction and mortality. The aboveground complexity of interactions between eukaryotes has been investigated through decades. Resulting biotope affiliations of arthropods reflect specific host-plant strategies (Gange 2000; Gange et al. 2002; Dennis et al. 2004, 2005) until the arthropods' biological status becomes affected by exploitation or environmental disturbance (Gange et al. 2002, 2005; Mulder et al. 2005b).

The mobility of animals remains a scientific problem in the delimitation - or even in the definition - of land community units, which may lead to contrasting conclusions. For example, Werger (1978) pointed out the existence of conflicting distribution patterns in southern Africa between boundaries based on "Zoochoria" derived from the biogeography of either herptiles, birds, mammals or plants. However, for many invertebrates, mobility within the soil system is not a serious problem. In fact, the degree of non-specialised feeders belowground becomes much higher than aboveground as soon as these invertebrates are large enough for an active and continuous food research. Most populations fluctuate strongly and reflect prey species outbreaks and habitat destruction (Bengtsson et al. 
2002; Melián and Bascompte 2002; Cox and Moore 2005; Begon et al. 2006). Stochastic trends in the temporal occurrence of species and in the spatial variation in soil resources (Farley and Fitter 1999; Ebenman and Jonsson 2005) remain severe limitations for biologically realistic demographic models. Moreover, direct observations of interactions in a soil system are scarce and it remains questionable whether the increase of biodiversity per se, rather than the differentiation of the functional diversity related to attributes such as body size, stress tolerance, mobility and feeding strategy, contributes to an increased ecosystem stability (Bengtsson 1998; Setälä 2000, 2002; Loreau et al. 2002; Begon et al. 2006).

Intensified land use, environmental toxicity and disturbance are known to cause reductions in both the number of species within functional groups as in the population density of specific trophic levels (Bengtsson et al. 2005; Mulder et al. $2005 c, d$ ). A functional group is a group of related organisms that perform the same function in an ecosystem, e.g. nitrogen-fixing bacteria or bacterial-feeding invertebrates. Thus, food choice (FOM or SOM) and other attributes (such as body size) discriminate soil invertebrates from each other. From this perspective, the soil systems offer unique possibilities to study the interactions between and within the five kingdoms (Monera, Protoctista, Fungi, Plantae and Animalia). In an attempt to describe the main interactions within the animal kingdom this review is focusing on, I will introduce briefly some invertebrates that will be mentioned in this review. Soil nematodes are very small, widespread, abundant and diverse (Fitter et al. 2005). Their likely total biodiversity on Earth is as high (500,000 species) as that of viruses and is even higher than the estimated total number of bacterial species (Cox and Moore 2005). Nematodes have promising characteristics as field bioindicators (Breure et al. 2005) and a facultative selffertilising reproduction that enables a laboratory fine-tuning (Walker et al. 2000). The physiognomic characters of the nematodes' buccal cavities (Yeates et al. 1993; Warwick and Clarke 1998) can be chosen to assess effects on the basal fauna (Mulder et al. 2003a, 2005d) and to express the efficiency of soil decomposition processes (Table 1 ). In contrast to non-parasitic nematodes, collembolans (springtails) are often selective or even preferential species. They belong to the most diverse taxonomic group known on Earth, the insects (Cox and Moore 2005), and are among the most abundant arthropods, with a long evolutionary history (Fountain and Hopkin 2005). Often regarded as essential decomposers in surface litter and in root litter (Table 2), collembolans show a marked preference for FOM (Klironomos et al. 1999; Mikola et al. 2002) and fungal hyphae (Fountain and Hopkin 2005; Mulder et al. 2005a). Although also other invertebrates, like mites, are essential in the food web (Moore et al. 1988), enchytraeids are possibly "key elements" of the decomposer community (Didden et al. 1997; Laakso and Setälä 1999; Didden 2003). All these invertebrates are dependent on each other and compete with each other (Figs. 1 and 2; Table 1). Earthworms are correctly considered "ecosystem engineers" due to their ability to change their soil habitat (or even create new habitats for other organisms) through various activities (Brown 1995) but show a weak correlation between their occurrence and the soil organic matter content (Römbke et al. 2005). The occurrence and the numerical abundance of these soil invertebrates offer valuable information on ecosystem functioning and ecosystem services. In Table 2, we examine briefly what is gained and what is lost through aggregation of bioindicators and ecological processes (Breure et al. 2005; Meyerson et al. 2005). 


\section{Table 1 Proxies (ecological parameters) for ecosystem services}

\begin{tabular}{|c|c|c|}
\hline \multirow{2}{*}{\begin{tabular}{|l|}
$\begin{array}{l}\text { Ecosystem } \\
\text { service }\end{array}$ \\
\\
$\begin{array}{l}\text { Supply of } \\
\text { nutrients }\end{array}$ \\
\end{tabular}} & \multicolumn{2}{|c|}{ Important ecological parameters and literature } \\
\hline & $\begin{array}{l}\text { Primary production, main } \mathrm{C} \\
\text { pathways, mobilisation of soil } \mathrm{N}, \\
\text { bacteria to fungi ratio, translocation } \\
\text { of fungi by earthworms }\end{array}$ & $\begin{array}{l}\text { Bardgett et al. 1999, 2003, 2005; Beerling and } \\
\text { Woodward 2001; Chapin and Eviner 2003; Cole } \\
\text { et al. 2004; Gange 1993; Klironomos et al. } \\
\text { 2000; Legendre and Rivkin 2002; Mulder et al. } \\
\text { 2003a, 2005d; Scheu and Setälä 2002; Setälä } \\
\text { 2002; Wardle 1995, 2002; Wardle et al. 1999, } \\
\text { 2004 }\end{array}$ \\
\hline Soil structure & $\begin{array}{l}\text { Enchytraeids and earthworms, } \\
\text { nematode channel ratio, bacteria to } \\
\text { fungi ratio, fresh organic matter, } \\
\text { priming effect, soil organic matter, } \\
\text { soil acidity (power of hydrogen) }\end{array}$ & $\begin{array}{l}\text { Breure 2004; Breure et al. 2005; Didden 2003; } \\
\text { Fontaine et al. 2003, 2004; Ingham et al. } \\
\text { 1985; Laakso and Setälä 1999; Liiri et al. } \\
\text { 2002; Moore et al. 2004; Mulder et al. 2003a, } \\
\text { 2003b, 2005a,d; Needham et al. 2004; Scheu } \\
\text { and Setälä 2002; Setälä 2002; Wardle et al. } \\
\text { 2004; Yeates 2003 }\end{array}$ \\
\hline $\begin{array}{l}\text { Water } \\
\text { regulation }\end{array}$ & $\begin{array}{l}\text { Earthworms abundance, colloids, } \\
\text { bacteria to fungi ratio, SOM, } \\
\text { groundwater level }\end{array}$ & $\begin{array}{l}\text { Breure et al. 2005; Brown 1995; Didden 2003; } \\
\text { Needham et al. 2004; Van Noordwijk et al. } \\
1998\end{array}$ \\
\hline $\begin{array}{l}\text { Supply of clean } \\
\text { shallow water }\end{array}$ & $\begin{array}{l}\text { Specific activity of bacteria and } \\
\text { fungi; pollutants lower than critical } \\
\text { threshold; extent of leaching of } \\
\text { nitrogen, phosphate and } \\
\text { halogenated pollutants; activity of } \\
\text { the N cycle }\end{array}$ & $\begin{array}{l}\text { Begon et al. 2006; Breure et al. 2005; Cook } \\
\text { and Allan 1992; Ingham et al. 1985; Mulder et } \\
\text { al. 2005b,d,e; Perez-Moreno and Read 2001; } \\
\text { Wardle 2002; Wardle et al. } 2004\end{array}$ \\
\hline $\begin{array}{l}\text { Supply of clean } \\
\text { deep } \\
\text { groundwater }\end{array}$ & $\begin{array}{l}\text { Numerical abundance and } \\
\text { biodiversity of archaea and bacteria, } \\
\text { extent of washout of nitrogen and } \\
\text { phosphate, clean soil }\end{array}$ & $\begin{array}{l}\text { Begon et al. 2006; Breure 2004; Breure et al. } \\
\text { 2005; Fitter et al. 2005; Legendre and Rivkin } \\
\text { 2002; Mulder et al. 2003a, 2005d,e }\end{array}$ \\
\hline $\begin{array}{l}\text { Pest control in } \\
\text { agriculture }\end{array}$ & $\begin{array}{l}\text { Agrobiodiversity, genetic resources, } \\
\text { biological control of pathogens } \\
\text { microbial abundance, bacteria to } \\
\text { fungi ratio, (arbuscular) mycorrhizal } \\
\text { fungi }\end{array}$ & $\begin{array}{l}\text { Begon et al. 2006; Cairney 2000; Fountain and } \\
\text { Hopkin 2005; Gange et al. 2005; Hammer et } \\
\text { al. 2003; Watkinson and Freckleton } 1997\end{array}$ \\
\hline $\begin{array}{l}\text { Resilience and } \\
\text { resistance }\end{array}$ & $\begin{array}{l}\text { Functional diversity, allometric } \\
\text { interactions, length of the trophic } \\
\text { links, food web structure }\end{array}$ & $\begin{array}{l}\text { Dunne 2005; Jonsson et al. 2005; Mulder et al. } \\
\text { 2005c,d; Reuman and Cohen 2004, 2005; } \\
\text { Wardle et al. 2004; West and Brown 2005; } \\
\text { Woodward et al. } 2005\end{array}$ \\
\hline
\end{tabular}


Table 2 Biota and ecosystem functioning [processes modified from Hendrix et al. (1990), Giller et al. (1997), and Breure (2004)]

\begin{tabular}{|c|c|c|}
\hline & Nutrient cycling & Soil structure and aggregation \\
\hline \multirow{3}{*}{$\begin{array}{l}\text { Microflora (bacteria }+ \\
\text { fungi) }\end{array}$} & Catabolize fresh organic matter & $\begin{array}{l}\text { Bacteria produce compounds that } \\
\text { bind aggregates }\end{array}$ \\
\hline & Mineralize and immobilize nutrients & $\begin{array}{l}\text { Fungal hyphae entangle particles } \\
\text { on to aggregates }\end{array}$ \\
\hline & Carbon sequestration (detritus) & Passive fungal hyphae \\
\hline \multirow{3}{*}{$\begin{array}{l}\text { Microfauna } \\
\text { (Nematoda, some } \\
\text { Acarina) }\end{array}$} & $\begin{array}{l}\text { Regulate the population of their microbial } \\
\text { prey (bacterial and hyphal-feeding } \\
\text { nematodes) }\end{array}$ & May affect aggregate structure \\
\hline & $\begin{array}{l}\text { Fragment plant roots and transport FOM } \\
\text { (hyphal and plant-feeding nematodes) }\end{array}$ & Mix organic particles \\
\hline & $\begin{array}{l}\text { Alter nutrient turnover in the rhizosphere } \\
\text { (all nematodes) }\end{array}$ & Redistribution of nutrients \\
\hline \multirow{3}{*}{$\begin{array}{l}\text { Mesofauna (most } \\
\text { Acarina, all } \\
\text { Collembola, } \\
\text { Enchytraeidae) }\end{array}$} & $\begin{array}{l}\text { Regulate the population of their microbial } \\
\text { prey (microphytophagous arthropods) and } \\
\text { of the nematofauna (through nematode- } \\
\text { feeding mites) }\end{array}$ & $\begin{array}{l}\text { Affect aggregate structure and } \\
\text { produce faecal pellets }\end{array}$ \\
\hline & $\begin{array}{l}\text { Fragment plant roots and transport FOM } \\
\text { (panphytophagous arthropods and } \\
\text { enchytraeids) }\end{array}$ & $\begin{array}{l}\text { Mix organic particles, promote } \\
\text { humification }\end{array}$ \\
\hline & $\begin{array}{l}\text { Alter nutrient turnover in the rhizosphere } \\
\text { (all animals) }\end{array}$ & $\begin{array}{l}\text { Creation of biopores, } \\
\text { redistribution of nutrients }\end{array}$ \\
\hline \multirow{4}{*}{$\begin{array}{l}\text { Macrofauna } \\
\text { (Lumbricidae) }\end{array}$} & $\begin{array}{l}\text { Fragment plant roots and transport FOM } \\
\text { and SOM }\end{array}$ & $\begin{array}{l}\text { Mix organic and mineral particles, } \\
\text { promote humification }\end{array}$ \\
\hline & Enhance microbial activity & $\begin{array}{l}\text { Passive redistribution of } \\
\text { microorganisms through animals' } \\
\text { gut }\end{array}$ \\
\hline & Carbon sequestration & \multirow{2}{*}{$\begin{array}{l}\text { Earthworms building compact } \\
\text { structures, produce faecal pellets, } \\
\text { creation of biopores redistribution } \\
\text { of nutrients }\end{array}$} \\
\hline & & \\
\hline
\end{tabular}


Naturwissenschaften Volume 93, Number 10 / October, 2006 Pages 467-479 


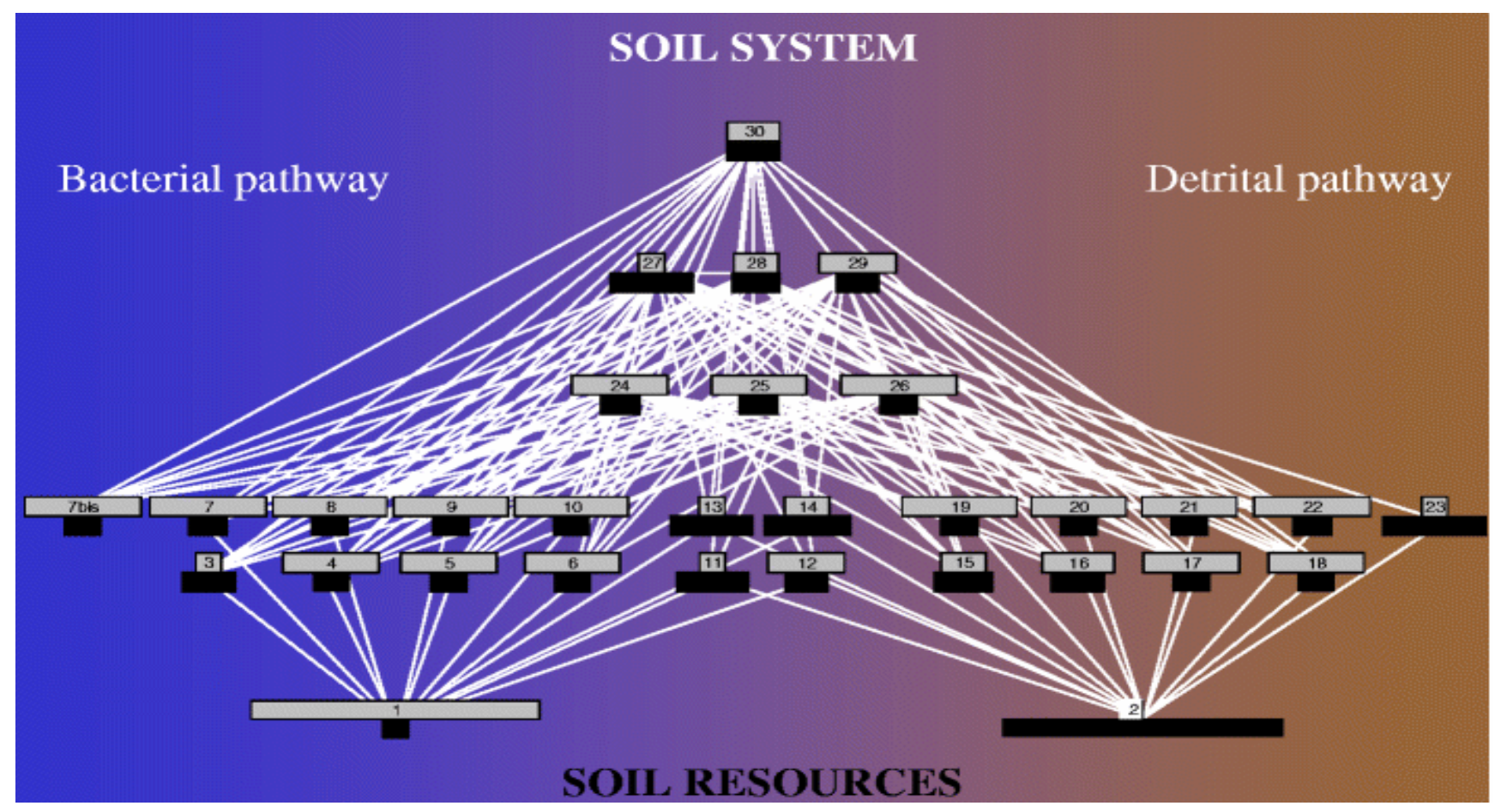

Fig. 2 Unlumped network of a Dutch agro-ecosystem on Pleistocene sand (same case study as next figure, see Mulder et al. 2005c for more details), depicting the two distinct energy pathways from the primary resources (1, bacterial population on the left, and 2, FOM + SOM on the right). This picture shows the energetic setup in terms of average body mass and density. In fact, the width of the horizontal bars shows for each taxon (mostly at genus level) the relative rank of body mass (log10 kilogram, averages per taxon) and numerical abundance (log10 individuals per kilogram of dry soil) as defined in Cohen et al. (2003) and Jonsson et al. (2005). The larger the black (grey) bar, the bigger (abundant) the organism. Horizontal position is arbitrary. 3, Histiostoma; 4, Diplogasteroides; 5, Panagrolaimidae; 6, Alaimus; 7, Rhabditidae (their Dauerlarvae resting stage is given as 7bis); 8, Teratocephalidae; 9, Plectidae; 10, Cephalobidae; 11, Isotoma; 12, Eupelops; 13, Hypogastrura; 14, Sminthurinus; 15, Henlea; 16, Enchytraeus; 17, Anguinidae; 18, Aphelenchoididae; 19, Dolichodoridae; 20, Paratylenchus; 21, Trichodoridae; 22, Tylenchidae; 23, Lumbricus; 24, Qudsianematidae; 25, Tripyla; 26, Dorylaimus; 27, Uropoda; 28, Alliphis; 29, Arctoseius; 30, Scutacaridae 


\section{Belowground balance?}

Soil animals are important for the functioning of the belowground ecosystem with respect to degradation of organic material, nutrient cycling, soil structure and texture, and water regulation (Table 1). A soil invertebrate dispersal over broad spatial scales is supposed to favour their generalism and plasticity (Bardgett 2002; Sultan and Spencer 2002; De Deyn and Van der Putten 2005), in contrast to the evolutionary scenario for vascular plants, in which the spatial scales by which a possible local adaptation will be allowed to proceed are far reduced (cf. Werger 1978; Cohen 1994). Most terrestrial seed dispersal mechanisms, in fact, are far from exceeding $100 \mathrm{~m}$ (Cain et al. 2000; Ken Thompson, personal communication, 2004). For animals, body mass remains determinant for their spatially scaled predatory activity, for resulting interaction strengths between predator and prey and for the final link structure in any food web (Cohen et al. 2003; Solé et al. 2003; Dunne 2005; Woodward et al. 2005). Arthropod predators are usually one to five orders of magnitude larger than their prey, in terms of body mass (cf. Siemann et al. 1999), while nematode microbial grazers are five to ten orders of magnitude larger than their prey, in terms of average mass of bacterial cells (Mulder et al. 2005c). Separate energy pathways imply that arthropod predators feed on varying food web compartments at lower trophic levels at different points in time, thus temporarily linking them into the larger food web of the surface litter (Bardgett 2002; Begon et al. 2006). O'Connell and Bolger (1997) reported significant differences among microphytophages and predators in consuming/predating efficiency. An observed loss of decomposer species does not occur randomly, although idiosyncratic shifts in feeding guilds of the microarthropod community may appear inconsistent with the expected responses to land management (Mikola et al. 2002). Variations in body sizes and in related territory of either a consumer or a predator remain key parameters for any organism (De Deyn and Van der Putten 2005). Therefore, intraguild competition with other organisms with similar body sizes or with comparable ecophysiological traits has always to be taken into account (Wardle and Yeates 1993; Wardle et al. 1999; Siemann et al. 1999; Cohen et al. 2003; Mulder et al. 2003a, 2005a; Zolda 2006). Figure 2 shows that the observed variances at genus level between either the numerical abundance of all soil organisms or between their average body mass across the food web (trophic pyramid) are huge. The clusters of bacterial-feeding nematodes on the left and hyphal- and plant-feeding nematodes on the right show the two different energy channels in my case study (please compare this figure with the aforementioned Fig. 1), from labile resources (bacterial population as a whole) to recalcitrant substrate (root litter, exudates and fungal hyphae, and FOM+SOM).

The existence of different patterns within and between food webs is in agreement with the complementarity action of the occurring "energy transfer agents" (the soil nematodes and enchytraeids of Table 2) vs the "habitat engineer agents" (such as the earthworms). Each soil food web consists of a wide variety of living organisms with different numerical abundances and dry weight. The smallest soil organisms (i.e. bacterial cells and fungal spores) dominate in terms of numerical abundance and catabolic activity in the ecosystem (Fig. 2; Table 2). These microorganisms are, in fact, directly involved in the decomposition process of the organic matter and act as nutrient sink in the soil (Van Noordwijk et al. 1998). Both previous figures show how FOM primary decomposers (fungi) make carbon available for other microbes (cf. Högberg and Högberg 2002; Fontaine et al. 2004), whereas FOM secondary decomposers (consumers: Collembola and, to a much lesser extent, Enchytraeidae) contribute to the removal of dissolved organic carbon (cf. Filser 2002). These opposite processes that occur at the same time probably explain the lack of statistical evidence in many laboratory studies under controlled conditions. 
Photosynthetic carbon allocated belowground can either become stored in roots (for subsequent growth and respiration) or released as exudates. Those rootderived compounds lost by exudation include low molecular mass exudates, secretions, polysaccharide mucilages and lysate (Bardgett et al. 1998; Bonkowski 2004; Moore et al. 2004; De Boer et al. 2005). As the (infested) roots are an important source of carbon for microbes (Coleman et al. 1983; Yeates et al. 1998), it is likely that any changes of FOM in perennial grasslands may significantly affect the functional diversity and the metabolic activity of rhizosphere communities (Table 1, 'supply of nutrients' and 'soil structure'). In an ideal sequence of increasing resistance to the breakdown occurring during decomposition processes, the residual resources of organic carbon are sugars < starch < hemicellulose and proteins < cellulose < lignins < suberins < cutins (Begon et al. 2006). Some more complex, refractory litter components, like cork and plant cuticles, can even resist to microbial attack and organic decomposition for millions of years (Mulder et al. 2000). Therefore, the total organic matter is highly variable in space and time according to soil depth, aboveground vegetation and global change (Van Noordwijk et al. 1998). In the upper $75 \mathrm{~cm}$ of soil of the Netherlands, for example, SOM varies between 2 and $60 \%$, mainly according to soil patterns, not to differences in land management (Mulder et al. 2005e). On the contrary, the highly variable fresh carbon litter input remains strictly related to the type of vegetation and the kind of management regime. This trend is explainable by the correlation between SOM (in the form of either intra-aggregate or organomineral complexes) and land use change, as only a conversion from cultivated use to perennial vegetation enhance the physical protection of the carbon storage.

Surface mixing by soil invertebrates is probably one of the most important processes (Table 1). Close relationships between FOM and soil invertebrates were clearly detectable at any trophic level. For instance, Bengtsson et al. (1997) demonstrate that fungivores and bacterivores showed mixed responses to harvesting in a Scots pine forest. In fact, panphytophagous microarthropods and fungi responded positively to organic management, while there seemed to be no direct or robust effects on the bacteria (Bengtsson et al. 2005; Mulder et al. 2003a, 2005c). Regardless of FOM, the predators' numerical abundances were usually much higher in grasslands under organic management than in conventional ones (Mulder et al. 2003a, 2005c; Bengtsson et al. 2005). The importance of the quality of FOM and its implications for microbial communities has been further discussed by Bardgett et al. (1998) and Dawson et al. (2000).

\section{Density-dependent life}

Nicholson $(1933,1954)$ claimed at first that the true balance of nature was a result of a density-dependent population ecology (among others through intraspecific competition). Such "regulating effects" in Nicholson's deterministic view started a polemic, as stable states do not exist. Even under environmental conditions that are held constant for a certain time span, the ecosystem functioning and the ecosystem stability are part of a continuous, dynamic process. We should actually avoid the term "equilibrium", as this word seems to exclude any form of dynamics. We can still understand better Nicholson's view using the so-called strong definition of equilibrium: "the sum of the negative feedbacks between components (should) be stronger than the sum of the positive feedbacks" (Berryman 1991). The classical feedbacks are prey-predator links (Nicholson and Bailey 1935; Ebenman and Jonsson 2005), plant-microbe (pathogenic or mutualistic) interactions (Klironomos 2002; Bever 2003) and nested sets of cycles of adaptive change covering spatial patterns and temporal trends (Holling 1973, 1992). Under relatively stable and benign physical conditions of the environment, these feedbacks will determine on ecological scale 
the soil system and its performance (ecosystem functioning) by promoting the most competitive species (Figs. 1 and 2). These findings suggest to a certain extent that ecosystem functioning seems to be driven more by the numerical abundances $\mathrm{N}$ of organisms than by their body mass $\mathrm{M}$ (mostly derived from their average body size) or by their total biomass $(\mathrm{N} \times \mathrm{M})$, in apparent contrast to previous studies (Cousins 1980, 1987).

The ecosystem functioning may become recognizable with macroecological approaches which rely on the numerical abundance and the (species-specific) body mass of soil organisms. A widely used method is allometry. 'Allometry' is etimologically derived from the Greek words $a^{\prime} \lambda \lambda$ o (other) and $\mu \varepsilon T \rho \circ$ (measure) and refers to the (dis)proportionate changes of dimensions of organisms and to their development as relative proportions of a whole. Allometry is suitable to characterize the emergent characteristics of large data sets of organisms distributed in space and time (Jonsson et al. 2005; Marquet et al. 2005) and can offer a reliable mathematical tool to outflank the difficulties of recognising many of the trophic interactions occurring belowground. The combination of food web data with species $\mathrm{M}$ and $\mathrm{N}$ data has been explored by Cohen et al. (2003), Reuman and Cohen (2004, 2005), Jonsson et al. (2005) and Mulder et al. (2005c). Let us assume that no species is isolated and that the investigated food web has a single connected component. In that case, the position of any species in a food chain may be defined as follows: in any (M, N) web like that of Fig. 3, species a was said to be below species $b \neq a$ in a trophic link if species a was eaten by species $b$ or if species a was below any species that was below species $b$ (see Reuman and Cohen 2004, 2005 for more details). Of the resulting trophic links in this case study, about three fourths show animals preying on (abundant) organisms with a smaller body mass (prey a plotted above and on the left of consumer/predator $b$ ) and these trophic roles vary significantly across taxonomic orders. Several density scaling relationships have been postulated for ecosystems, among others the minimum size of a given population at a given time, their population energy use scaling and their biomass distribution. In Fig. 3, the primary decomposers show a much higher numerical density (greater size of their enchytraeids and collembolans populations) than that predicted by their body mass $M$ (all the FOM-related decomposers rely much above the regression line of the complete soil fauna). Primary decomposers are actually secondary consumers, as they are feeding on dead organic matter already affected by bacterial digestion. It is surprising that similar aboveground trends can be recognised among mammalian secondary consumers, whose anomalous metabolic scaling also seems to be due to local resource availability (Damuth 1981; Marquet et al. 2005). Like these largest consumers, the smallest producers of any ecosystem, the bacterial cells, also seem to be numerically much more abundant and metabolically more active than expected from an allometric point of view (Reuman et al. 2006).

Fig. 3 What can we learn from a soil food web if we know the average body mass $M(\log 10$ dry weight) and the numerical abundance $N$ (log10 density per square meter) of each taxon in it? This picture plots the allometric relationship between the soil invertebrates under one Dutch bio-organic grassland on sand (Mulder et al. 2005c). Each dot represents a genus; the relationship between body mass and body length for nematodes or enchytraeids is different from that for arthropods. All pictures are unscaled. Although the density at community level and the related territory at species level do vary (larger animals live longer and their zone of impact is larger), the numerical abundances within microfauna and mesofauna are effectively comparable, as the census area (in this case, $1 \mathrm{~m} 2$ ) is constrained by field practicalities never to vary in size. Bigger invertebrates like earthworms obviously expend more energy than the smaller organisms such as soil nematodes. $\mathrm{N}$ depends allometrically on $\mathrm{M}$ if and only if the biomass depends 
allometrically on $M$ (Cohen et al. 2003). In this case, the biomass exponent derived from the inverse linear relationship between $\mathrm{N}$ and $\mathrm{M}$ of all occurring organisms is equal to 0 (between -0.05 and 0.05 across trophic levels). When this double-logarithmic linear relationship has a slope equal to the unity $(\beta=1)$, the two components $\mathrm{M}$ and $\mathrm{N}$ develop isometrically (stable soil system and high soil quality). Part of the linear regression of the complete food web of Fig. 2 is shown here. In this case, the slopes equal to $-1.010 \pm 0.101$ (with bacteria, $\mathrm{P}=10-14$ ) and $-0.649 \pm 0.109$ (without bacteria, $\mathrm{P}=10-7$ )

Bengtsson et al. (1998) showed that, in a "donor system" like the detrital soil food web, changes in the numerical abundance of organisms after harvesting (FOM) were consistently dependent on the trophic position within the food web, with more mobile animals more affected by FOM (see Collembola and Enchytraeidae in Figs. 1 and 3). Many effects that could be ascribed to FOM were also found among predators. Uropodina are probably the main predators in this case study (Fig. 2). Regardless of the amount of taxa that are at the same time grazing on bacteria and feeding on detritus (i.e. dead plant material) and fungal mycelium, the slopes of the regression lines of the estimates of $\mathrm{M}$ on $\mathrm{N}$ and $\mathrm{N}$ on $M$ are both significant (Reuman et al. 2006;

http://www.blackwellpublishing.com/products/journals/suppmat/ELE/ELE704/ELE 704sm.htm). Merging at taxonomic level does not introduce statistical biases: mean weight and standard deviation show the same universal similarities (or differences) in the variation patterns associated with the size of an organism (Siemann et al. 1999; Marquet et al. 2005; Mulder et al. 2005c).

The situation with the microbial community is different, as many different bacterial species were lumped together. If bacteria could be distinguished into taxonomically narrower groups, the numerical abundance of each specific group would be obviously much smaller and the point would be replaced by a cloud with almost the same average cell volume. As the microflora is known to be sensitive to environmental stress, the correct assessment of the microbial dynamics remains extremely important for the true understanding of ecosystem functioning (Ingham et al. 1985; Setälä et al. 1998; Griffiths et al. 2000).

\section{Does the ecosystem recover?}

Stress is supposed to have little effect on the soil system due to a widespread stabilising feedback. However, any restoration of the original environmental conditions before changes occurred is not per se sufficient to induce a shift back of the ecosystem. The resulting stability is not only due to the effects of stress on organisms but can be ascribed to the phenology of organisms, i.e. seasonality, weather fluctuations and sampling period. Any system reacts at the same time to continuous changes (long-term trends) as to abrupt perturbations (short-term trends). Sustainable development remains the overarching goal based on assumptions about which system state is desirable and depends on the temporal trends and spatial patterns of the investigation.

In most terrestrial ecosystems, the approach of Hunt et al. (1987) is extremely reliable at the level of overall respiration and mineralisation fluxes. An intriguing new point is that other ways have to be explored to state the extent up to which ecosystems can be regarded as 'stable' (sensu Moore and Hunt 1988). More trophic levels can be inferred from a higher number of taxa, whereas the increase in diversity of the responses to environmental fluctuations is supposed to increase the ecosystem stability according to Ives et al. $(1999,2000)$. They argue that the variances in biomass at the species level and community level decrease as the number of species and the reduction in community biomass increase. However, 
this is not entirely true. In fact, the variance of biomass at community level is independent from the number of species within the same community (or trophic level). For this purpose, the use of a third energy channel (plant roots) to describe the energy flux as originally proposed by Hunt et al. (1987), in addition to the three other main resources (substrate, bacteria and fungi), provides striking evidence to assess the actual role of functional redundancy (Fig. 1). The assessment of the efficiency in process regulation (energy fluxes) in the detrital soil food webs may provide an answer to this question. In this study, I have chosen for the debated density-dependent approach, as recent studies (see previous section) clearly show whether community differences in the densitybody mass relationships are large enough to influence the ecosystem functioning and the ecological services of the soil biota.

Fitter et al. (2005) see the unexplained empirical biodiversity of small organisms as a new ecological challenge. According to this National Environment Research Council essay, it is not unlikely that this disproportionately high biodiversity is related to the extreme physical heterogeneity of soils. However, they postulate limited migration ability on all spatial scales of most of these soil organisms, resulting in systems that are always far from equilibrium. Yet, this is not the case if the fractal-like density dependence distribution (here as three-quarter power of body mass) from molecules to bacterial cells and animals' taxa is considered (West et al. 2002). The rationale behind my choice is the wide extent to which several fundamental biological processes often manifest an extraordinary simplicity regardless of the taxa when viewed as a power function of body size (West et al. 2002; West and Brown 2005; Allen et al. 2005).

Natural selection and self-organisation jointly interact as a new way to view the evolution of ecological systems. The constrains on population growth due to resource limitation can be easily seen as a carrying capacity of ecosystems based on density dependence (Del Monte-Luna et al. 2004). Such a carrying capacity is implicitly equal to the total number of individuals $\mathrm{N}$ a given ecosystem can maintain, seen as the biological and physical characteristics of the ecosystem itself. The latter view is becoming the dominant one in landscape ecology but can be easily applied also to ecosystem functioning and metabolic scaling. Thus, simple graphical and quantitative indicators of community composition allow for the illustration of ecosystem functioning according to its allometric $\mathrm{N}$ and $\mathrm{M}$ components. As evidence of important consequences of the distribution of body mass $M$ for the stability of a food web (in the present case, the "equilibrium" sensu Nicholson 1933) is rapidly increasing in both pelagic systems and soil systems (Cohen et al. 2003; Reuman and Cohen 2004, 2005; Mulder et al. 2005c), I believe that allometric food web topology allows for the recognition of altered magnitude of interaction strengths in the propagation of stress and environmental disturbance across trophic levels. Energy fluxes can, in fact, be derived from the allometric slope and the intercept of the linear regression for a complete soil community. These slopes measure, among others, the relative occurrence of small (microfauna) to large species (macrofauna) in relation to their prey/resources. Allometric slopes tend to be less negative in sustainable and productive farms and forests, and more steeply negative in rather stable but unproductive natural soil systems, such as dry heathlands.

Real stable states do not exist, either in agroenvironments or in nature. Although unobtainable, policy-makers aim these 'static conditions'. Both the Dutch and the European jurisdiction on physical planning show a compulsory role of conservation ecology and biodiversity policy in decision-making and legislation (Breure et al. 2005). However, most policies simply require a so-called "red list" of targets for legal conservation status. The assessment of the efficiency in process regulation in the detrital soil food webs enables the provision of an 
Naturwissenschaften Volume 93, Number 10 / October, 2006 Pages 467-479

answer to this management question. This is an important argument to show that allometric aspects of soil systems are good indicators for sustainability and for ecological stability. Such information does not follow directly from chemical and physical characterisation of soils. 


\section{References}

Allen AP, Gillooly JF, Brown JH (2005) Linking the global carbon cycle to individual metabolism. Funct Ecol 19:202-213

Ashman MR, Hallett PD, Brookes PC (2003) Are the links between soil aggregate size class, soil organic matter and respiration rate artefacts of the fractionation procedure? Soil Biol Biochem 35:435-444

Bardgett RD (2002) Causes and consequences of biological diversity in soil. Zoology 105:367-374

Bardgett RD, Wardle DA, Yeates GW (1998) Linking above-ground and below-ground interactions: how plant responses to foliar herbivory influence soil organisms. Soil Biol Biochem 30:1867-1878

Bardgett RD, Cook R, Yeates GW, Denton CS (1999) The influence of nematodes on below-ground processes in grassland ecosystems. Plant Soil 212:23-33

Bardgett RD, Streeter TC, Bol R (2003) Soil microbes compete effectively with plants for organicnitrogen inputs to temperate grasslands. Ecology 84:1277-1287

Bardgett RD, Bowman WD, Kaufmann R, Schmidt SK (2005) A temporal approach to linking aboveground and belowground ecology. Trends Ecol Evol 20:634-641

Beerling DJ, Woodward FI (2001) Vegetation and the terrestrial carbon cycle: modelling the first 400 million years. Cambridge University Press, Cambridge

Begon M, Townsend CR, Harper JL (2006) Ecology: from individuals to ecosystems. Blackwell, Oxford

Bengtsson J (1998) Which species? What kind of diversity? Which ecosystem function? Some problems in studies of relations between biodiversity and ecosystem function. Appl Soil Ecol 10:191-199

Bengtsson J, Persson T, Lundkvist $\mathrm{H}$ (1997) Long-term effects of logging residue addition and removal on macroarthropods and enchytraeids. J Appl Ecol 34:1014-1022

Bengtsson J, Lundkvist H, Saetre P, Sohlenius B, Solbreck B (1998) Effects of organic matter removal on the soil food web: forestry practices meet ecological theory. Appl Soil Ecol 9:137-143

Bengtsson J, Engelhardt K, Giller P, Hobbie S, Lawrence D, Levine J, Vilà M, Wolters V (2002) Slippin' and slidin' between the scales: the scaling components of biodiversity-ecosystem functioning relations. In: Loreau M, Naeem S, Inchausti P (eds) Biodiversity and ecosystem functioning: synthesis and perspectives. Oxford University Press, Oxford, pp 209-220

Bengtsson J, Ahnström J, Weibull A-C (2005) The effects of organic agriculture on biodiversity and abundance: a meta-analysis. J Appl Ecol 42:261-269

Berryman AA (1991) Stabilization or regulation: what it all means! Oecologia 86:140-143

Bever JD (2003) Soil community feedback and the coexistence of competitors: conceptual framework and empirical tests. New Phytol 157:465-473

Bonkowski M (2004) Protozoa and plant growth: the microbial loop in soil revisited. New Phytol 162:617-631

Bradford MA, Jones TH, Bardgett RD, Black HIJ, Boag B, Bonkowski M, Cook R, Eggers T, Gange AC, Grayston SJ et al (2002) Impacts of soil faunal community composition on model grassland ecosystems. Science 298:615-618

Breure AM (2004) Ecological soil monitoring and quality assessment. In: Doelman P, Eijsackers HJP (eds) Vital soil: function, value and properties. Developments in soil science, vol 29. Elsevier Science, Amsterdam, pp 281-305

Breure AM, Mulder C, Römbke J, Ruf A (2005) Ecological classification and assessment concepts in soil protection. Ecotoxicol Environ Saf 62:211-229

Brown GG (1995) How do earthworms affect microfloral and faunal community diversity? Plant Soil 170:209-231

Cain M, Milligan B, Strand A (2000) Long-distance seed dispersal in plant populations. Am J Bot 87:1217-1227

Cairney JWG (2000) Evolution of mycorrhiza systems. Naturwissenschaften 87:467-475 
Chapin FS III, Eviner VT (2003) Biogeochemistry of terrestrial net primary production. In: Schlesinger WH (ed) Treatise on geochemistry, vol 8. Biogeochemistry. Elsevier, pp 215-247

Cohen JE (1994) Marine and continental food webs: three paradoxes? Philos Trans R Soc Lond B 343:57-69

Cohen JE, Jonsson T, Carpenter SR (2003) Ecological community description using the food web, species abundance, and body size. Proc Natl Acad Sci USA 100:1781-1786

Cole L, Staddon PL, Sleep D, Bardgett RD (2004) Soil animals influence microbial abundance, but not plant-microbial competition for soil organic nitrogen. Funct Ecol 18:631-640

Coleman DC, Reid CPP, Cole CV (1983) Biological strategies of nutrient cycles in soil systems. Adv Ecol Res 13:1-55

Cook BD, Allan DL (1992) Dissolved organic matter in old field soils: total amounts as a measure of available resources for soil mineralization. Soil Biol Biochem 24:585-594

Cousins SH (1980) A trophic continuum derived from plant structure, animal size and a detritus cascade. J Theor Biol 82:607-618

Cousins SH (1987) The decline of the trophic level concept. Trends Ecol Evol 2:312-316

Cox CB, Moore PD (2005) Biogeography: an ecological and evolutionary approach. Blackwell, Oxford

Damuth J (1981) Population density and body size in mammals. Nature 290:699-700

Dawson LA, Grayston SJ, Paterson E (2000) Effects of grazing on the roots and rhizosphere of grasses. In: Lemaire G, Hodgson J, De Moraes A, Nabinger C, De F Carvalho PC (eds) Grassland ecophysiology and grazing ecology. CAB International, Wallingford, Oxon, UK, pp 61-84

De Boer W, Folman LB, Summerbell RC, Boddy L (2005) Living in a fungal world: impact of fungi on soil bacterial niche development. FEMS Microbiol Rev 29:795-811

De Deyn GB, Van der Putten WH (2005) Linking aboveground and belowground diversity. Trends Ecol Evol 20:625-633

De Luca TH, Keeney DR (1993) Soluble anthrone-reactive carbon in soils: effect of carbon and nitrogen amendments. Soil Sci Soc Am J 57:1296-1300

Del Monte-Luna P, Brook BW, Zetina-Rejón MJ, Cruz-Escalona VH (2004) The carrying capacity of ecosystems. Glob Ecol Biogeogr 13:485-495

Dennis RLH, Hodgson JG, Grenyer R, Shreeve TG, Roy DB (2004) Host plants and butterfly biology. Do host-plants strategies drive butterfly status? Ecol Entomol 29:12-26

Dennis RLH, Shreeve TG, Arnold HR, Roy DB (2005) Does diet breadth control herbivorous insect distribution size? Life history and resource outlets for specialist butterflies. J Insect Conserv 9:187200

Didden W (2003) Oligochaeta. In: Markert B, Breure AM, Zechmeister H (eds) Bioindicators and biomonitors. Elsevier Science and Technology, London, pp 555-576

Didden W, Fründ HC, Graefe U (1997) Enchytraeids. In: Benckiser GE (ed) Fauna in soil ecosystems: recycling processes, nutrient fluxes and agricultural production. Marcel Dekker, New York, pp 135-172

Dunne JA (2005) The network structure of food webs. In: Pascual M, Dunne JA (eds) Ecological networks: linking structure to dynamics in food webs. Oxford University Press, Oxford, pp 27-86

Ebenman B, Jonsson T (2005) Using community viability analysis to identify fragile systems and keystone species. Trends Ecol Evol 20:568-575

Farley RA, Fitter AH (1999) Temporal and spatial variation in soil resources in a deciduous woodland. J Ecol 87:688-696

Filser J (2002) The role of Collembola in carbon and nitrogen cycling in soil. Pedobiologia 46:234-245 
Filser J, Mebes K-H, Winter K, Lang A, Kampichler C (2002) Long-term dynamics and interrelationships of soil Collembola and microorganisms in an arable landscape following land use change. Geoderma 105:201-222

Fitter AH, Sanders I (1992) Interactions with the soil fauna. In: Allen MF (ed) Mycorrhizal functioning. Chapman \& Hall, New York, pp 333-354

Fitter AH, Gilligan CA, Hollingworth K, Kleczkowski A, Twyman RM, Pitchford JW (2005) Biodiversity and ecosystem function in soil. Funct Ecol 19:369-377

Fontaine S, Barot S (2005) Size and functional diversity of microbe populations control plant persistence and long-term soil carbon accumulation. Ecol Lett 8:1075-1087

Fontaine S, Mariotti A, Abbadie L (2003) The priming effect of organic matter: a question of microbial competition? Soil Biol Biochem 35:837-843

Fontaine S, Bardoux G, Abbadie L, Mariotti A (2004) Carbon input to soil may decrease soil carbon content. Ecol Lett 7:314-320

Fountain MT, Hopkin SP (2005) Folsomia candida (Collembola): a "standard" soil arthropod. Annu Rev Entomol 50:201-222

Gange AC (1993) Translocation of mycorrhizal fungi by earthworms during early plant succession. Soil Biol Biochem 25:1021-1026

Gange AC (2000) Species-specific responses of a root- and shoot-feeding insect to arbuscular mycorrhizal colonization of its host plant. New Phytol 150:611-618

Gange AC, Brown VK (2002) Actions and interactions of soil invertebrates and arbuscular mycorrhizal fungi in affecting the structure of plant communities. Ecol Stud 157:321-344

Gange AC, Stagg PG, Ward LK (2002) Arbuscular mycorrhizal fungi affect phytophagous insect specialism. Ecol Lett 5:11-15

Gange AC, Brown VK, Aplin DM (2005) Ecological specificity of arbuscular mycorrhizae: evidence from foliar- and seed-feeding insects. Ecology 86:603-611

Giller KE, Beare MH, Lavelle P, Izac AMN, Swift MJ (1997) Agricultural intensification, soil biodiversity and agro-ecosystem function. Appl Soil Ecol 6:3-16

Griffiths BS, Ritz R, Bardgett RD, Cook R, Christensen S, Ekelund F, Sørensen E, Bååth E, Bloem J, De Ruiter P et al (2000) Stability of soil ecosystem-level processes following the experimental manipulation of soil microbial community diversity. Oikos 90:279-294

Hammer K, Arrowsmith N, Gladis T (2003) Agrobiodiversity with emphasis on plant genetic resources. Naturwissenschaften 90:241-250

Hartnett DC, Wilson GWT (1999) Mycorrhizae influence plant community structure and diversity in tallgrass prairie. Ecology 80:1187-1195

Hedlund K, Griffiths B, Christensen S, Scheu S, Setälä H, Tscharntke T, Verhoef H (2004) Trophic interactions in changing landscapes: responses of soil food webs. Basic Appl Ecol 5:495-503

Hendrix PF, Crossley DA Jr, Blair JM, Coleman DC (1990) Soil biota as components of sustainable agroecosystems. In: Edwards CA, Lal R, Madden P, Miller RH, House G (eds) Sustainable agricultural systems. Soil and Water Conservation Society, Ankeny, IL, pp 637-654

Högberg MN, Högberg P (2002) Extramatrical ectomycorrhizal mycelium contributes half the microbial biomass and produces, together with associated roots, half the dissolved organic carbon in a forest soil. New Phytol 154:791-795

Holling CS (1973) Resilience and stability of ecological systems. Annu Rev Ecol Syst 4:1-23

Holling CS (1992) Cross-scale morphology, geometry and dynamics of ecosystems. Ecol Monogr 62:447-502

Hunt HW, Coleman DC, Ingham ER, Ingham RE, Elliot ET, Moore JC, Rose SL, Reid CPP, Morley CR (1987) The detrital food web in a shortgrass prairie. Biol Fertil Soils 3:57-68 
Ingham RE, Trofymow JA, Ingham ER, Coleman DC (1985) Interactions of bacteria, fungi, and their nematode grazers: effects on nutrient cycling and plant growth. Ecol Monogr 55:119-140

Ives AR, Gross K, Klug JL (1999) Stability and variability in competitive communities. Science 286:542-544

Ives AR, Klug JL, Gross K (2000) Stability and species richness in complex communities. Ecol Lett $3: 399-411$

Jansa J, Mozafar A, Anken T, Ruh R, Sanders IR, Frossaard E (2002) Diversity and structure of AMF communities as affected by tillage in a temperate soil. Mycorrhiza 12:225-234

Jonsson T, Cohen JE, Carpenter SR (2005) Food webs, body size and species abundance in ecological community description. Adv Ecol Res 36:1-84

Klironomos JN (2002) Feedback with soil biota contributes to plant rarity and invasiveness in communities. Nature 417:67-70

Klironomos JN, Kendrick WB (1995) Stimulative effects of arthropods on endomycorrhizas of sugar maple in the presence of decaying litter. Funct Ecol 9:528-536

Klironomos JN, Kendrick WB (1996) Palatability of microfungi to soil arthropods in relation to the functioning of arbuscular mycorrhizae. Biol Fertil Soils 21:43-52

Klironomos JN, Hart MM (2001) Animal nitrogen swap for plant carbon. Nature 410:651-652

Klironomos JN, Bednarczuk EM, Neville J (1999) Reproductive significance of feeding on saprobic and arbuscular mycorrhizal fungi by the collembolan, Folsomia candida. Funct Ecol 13:756-761

Klironomos JN, McCune J, Hart M, Neville J (2000) The influence of arbuscular mycorrhizae on the relationship between plant diversity and productivity. Ecol Lett 3:137-141

Laakso J, Setälä H (1999) Sensitivity of primary production to changes in the architecture of belowground food webs. Oikos 87:57-64

Laakso J, Setälä H, Palojärvi A (2000) Influence of decomposer food web structure and nitrogen availability on plant growth. Plant Soil 225:153-165

Legendre L, Rivkin RB (2002) Pelagic food webs: responses to environmental processes and effects on the environment. Ecol Res 17:143-149

Liiri M, Setälä H, Haimi J, Pennanen T, Fritze H (2002) Relationship between soil microarthropod species diversity and plant growth does not change when the system is disturbed. Oikos 96:137-149

Loreau M, Downing A, Emmerson M, Gonzalez A, Hughes J, Inchausti P, Joshi J, Norberg J, Sala O (2002) A new look at the relationship between diversity and stability. In: Loreau M, Naeem S, Inchausti $\mathrm{P}$ (eds) Biodiversity and ecosystem functioning: synthesis and perspectives. Oxford University Press, Oxford, pp 79-91

Marquet PA, Quiñones RA, Abades S, Labra F, Tognelli M, Arim M, Rivadeneira M (2005) Scaling and power-laws in ecological systems. J Exp Biol 208:1749-1769

Melián CJ, Bascompte J (2002) Food web structure and habitat loss. Ecol Lett 5:37-46

Meyerson LA, Baron J, Melillo JM, Naiman RJ, O'Malley RI, Orians G, Palmer MA, Pfaff ASP, Running SW, Sala OE (2005) Aggregate measures of ecosystem services: can we take the pulse of nature? Front Ecol Environ 3:56-59

Mikola J, Bardgett RD, Hedlund K (2002) Biodiversity, ecosystem functioning and soil decomposer food webs. In: Loreau M, Naeem S, Inchausti P (eds) Biodiversity and ecosystem functioning: synthesis and perspectives. Oxford University Press, Oxford, pp 169-180

Moore JC, Hunt HW (1988) Resource compartmentation and the stability of real ecosystems. Science 261:906-909

Moore JC, Walter DE, Hunt HW (1988) Arthropod regulation of micro- and mesobiota in below-ground detrital food web. Annu Rev Entomol 33:419-439

Moore JC, Berlow EL, Coleman DC, De Ruiter PC, Dong Q, Hastings A, Johnson NC, McCann KS, Melville K, Morin PJ et al (2004) Detritus, trophic dynamics and biodiversity. Ecol Lett 7:584-600 
Mulder C, Janssen CR (1999) Occurrence of pollen and spores in relation to present-day vegetation in a Dutch heathland area. J Veg Sci 10:87-100

Mulder C, De Zwart D (2003) Assessing fungal species sensitivity to environmental gradients by the Ellenberg indicator values of above-ground vegetation. Basic Appl Ecol 4:557-568

Mulder C, Sakorafa V, Burragato F, Visscher H (2000) Ecohydrological perspective of phytogenic organic and inorganic components in Greek lignites: a quantitative reinterpretation. Earth Planet Sci Lett 179:167-181

Mulder C, De Zwart D, Van Wijnen HJ, Schouten AJ, Breure AM (2003a) Observational and simulated evidence of ecological shifts within the soil nematode community of agroecosystems under conventional and organic farming. Funct Ecol 17:516-525

Mulder C, Breure AM, Joosten JHJ (2003b) Fungal functional diversity inferred along Ellenberg's abiotic gradients: palynological evidence from different soil microbiota. Grana 42:55-64

Mulder C, Van Wijnen HJ, Van Wezel AP (2005a) Numerical abundance and biodiversity of belowground taxocenes along a pH gradient across the Netherlands. J Biogeogr 32:1775-1790

Mulder C, Aldenberg T, De Zwart D, Van Wijnen HJ, Breure AM (2005b) Evaluating the impact of pollution on plant-Lepidoptera relationships. Environmetrics 16:357-373

Mulder C, Cohen JE, Setälä H, Bloem J, Breure AM (2005c) Bacterial traits, organism mass, and numerical abundance in the detrital soil food web of Dutch agricultural grasslands. Ecol Lett 8:80-90

Mulder C, Dijkstra JB, Setälä H (2005d) Nonparasitic Nematoda provide evidence for a linear response of functionally important soil biota to increasing livestock density. Naturwissenschaften 92:314-318

Mulder C, Van Wezel AP, Van Wijnen HJ (2005e) Embedding soil quality in the planning and management of land use. Int J Biodiv Sci Manag 1:77-84

Needham SJ, Worden RH, McIlroy D (2004) Animal-sediment interactions: the effect of ingestion and excretion by worms on mineralogy. Biogeosciences 1:113-121

Nicholson AJ (1933) The balance of animal populations. J Anim Ecol 2:132-178

Nicholson AJ (1954) An outline of the dynamics of animal populations. Aust J Zool 2:9-65

Nicholson AJ, Bailey VA (1935) The balance of animal populations. Part I. Proc Zool Soc Lond 3:551598

O'Connell T, Bolger T (1997) Fungus fruiting bodies and the structure of fungus-microarthropod assemblages. Proc R Ir Acad 97B:249-262

Perez-Moreno J, Read DJ (2001) Nutrient transfer from soil nematodes to plants: a direct pathway provided by the mycorrhizal mycelial network. Plant Cell Environ 24:1219-1226

Read DJ, Perez-Moreno J (2003) Mycorrhizas and nutrient cycling in ecosystems-a journey towards relevance? New Phytol 157:475-492

Reuman DC, Cohen JE (2004) Trophic links' length and slope in the Tuesday Lake food web with species' body mass and numerical abundance. J Anim Ecol 73:52-866

Reuman DC, Cohen JE (2005) Estimating relative energy fluxes using the food web, species abundance, and body size. Adv Ecol Res 36:137-182

Reuman DC, Mulder C, Banašek-Richter C, Cattin Blandenier M-F, Breure AM, Den Hollander HA, Kneitel JM, Raffaelli D, Woodward G, Cohen JE (2006) Allometry of body size and abundance in 166 food webs: tests of the standard linear model. Rockefeller University

Römbke J, Jänsch S, Didden W (2005) The use of earthworms in ecological soil classification and assessment concepts. Ecotoxicol Environ Saf 62:266-277

Scheu S, Setälä H (2002) Multitrophic interactions in decomposer food-webs. In: Tscharntke T, Hawkins BA (eds) Multitrophic level interactions. Cambridge University Press, Cambridge, pp 223-264

Setälä H (1995) Growth of birch and pine seedlings in relation to grazing by soil fauna on ectomycorrhizal fungi. Ecology 76:1844-1851 
Setälä H (2000) Reciprocal interactions between Scots pine and soil food web structure in the presence and absence of mycorrhiza. Oecologia 125:109-118

Setälä H (2002) Sensitivity of ecosystem functioning to changes in trophic structure, functional group composition and species diversity in belowground food webs. Ecol Res 17:207-215

Setälä H, Laakso J, Mikola J, Huhta V (1998) Functional diversity of decomposer organisms in relation to primary production. Appl Soil Ecol 9:25-31

Siemann E, Tilman D, Haarstad J (1999) Abundance, diversity and body size: patterns from a grassland arthropod community. J Anim Ecol 68:824-835

Solé RV, Ferrer-Cancho R, Montoya JM, Valverde S (2003) Selection, tinkering, and emergence in complex networks: crossing the land of tinkering. Complexity 8:20-33

Sultan SE, Spencer HG (2002) Metapopulation structure favors plasticity over local adaptation. Am Nat 160:271-283

Van Noordwijk M, Martikainen P, Bottner P, Cuevas E, Rouland C, Dhillion SS (1998) Global change and root function. Glob Chang Biol 4:759-772

Walker DW, McColl G, Jenkins NL, Harris J, Lithgow GJ (2000) Evolution of lifespan in C. elegans. Nature 405:296-297

Wardle DA (1995) Impacts of disturbance on detritus food webs in agro-ecosystems of contrasting tillage and weed management practices. Adv Ecol Res 26:105-185

Wardle DA (2002) Communities and ecosystems: linking the aboveground and belowground components. Monographs in population biology 34. Princeton University Press

Wardle DA, Yeates GW (1993) The dual importance of competition and predation as regulatory forces in terrestrial ecosystems: evidence from decomposer food-webs. Oecologia 93:303-306

Wardle DA, Bonner KI, Barker GM, Yeates GW, Nicholson KS, Bardgett RD, Watson RN, Ghani A (1999) Plant removals in perennial grassland: vegetation dynamics, decomposers, soil biodiversity, and ecosystem properties. Ecol Monogr 69:535-568

Wardle DA, Bardgett RD, Klironomos JN, Setälä H, Van der Putten W, Wall DH (2004) Ecological linkages between aboveground and belowground biota. Science 304:1629-1633

Warwick RM, Clarke KR (1998) Taxonomic distinctness and environmental assessment. J Appl Ecol 35:532-543

Watkinson AR, Freckleton RP (1997) Quantifying the impact of arbuscular mycorrhiza on plant competition. J Ecol 85:541-546

Werger MJA (1978) Biogeography and ecology of Southern Africa. Junk, The Hague

West GB, Brown JH (2005) The origin of allometric scaling laws in biology from genomes to ecosystems: towards a quantitative unifying theory of biological structure and organization. J Exp Biol 208: 1575-1592

West GB, Woodruff WH, Brown JH (2002) Allometric scaling of metabolic rate from molecules and mitochondria to cells and mammals. Proc Natl Acad Sci USA 99:2473-2478

Woodward G, Ebenman B, Emmerson M, Montoya JM, Olesen JM, Valido A, Warren PH (2005) Body size in ecological networks. Trends Ecol Evol 20:402-409

Yeates GW (2003) Nematodes as soil indicators: functional and biodiversity aspects. Biol Fertil Soils 37:199-210

Yeates GW, Saggar S, Denton CS, Mercer CF (1998) Impact of clover cyst nematode (Heterodera trifolii) infection on soil microbial activity in the rhizosphere of white clover (Trifolium repens): a pulse labelling experiment. Nematologica 44:81-90

Yeates GW, Bongers T, De Goede RGM, Freckman DW, Georgieva SS (1993) Feeding habits in soil nematode families and genera-an outline for soil ecologists. J Nematol 25:315-331

Zolda P (2006) Nematode communities of grazed and ungrazed semi-natural steppe grasslands in Eastern Austria. Pedobiologia 50:11-22 